\title{
NEWS, EVENTS AND RESOURCES
}

\section{News}

Society for Longitudinal and Life course Studies (SLLS) conference

As reported in the last Issue of the journal, SLLS will become formally established at the Society's inaugural conference, to be held on September 22-24 in Clare College Cambridge, England. To support the conference, Longview, the think tank that initiated the establishment of the Society, joined forces with the European Science Foundation-sponsored EUCCONET (European Child Cohort Network) through which conference costs for many participants are being met. The response to the call for papers to the conference was excellent, with 180 abstracts for symposia, individual papers and posters received. We look forward to a successful meeting which will contribute further to the development of international longitudinal and life course research, providing a forum for collaboration, communication and debate. Future conferences are planned annually with different host countries each time. For further information go to:

wuw.longstudies.longviewuk.com/pages/conference.shtml

\section{Life course changes}

Two members of the LLCS Editorial Board have been appointed to key posts of much significance for longitudinal and life course researchers.
Paul Boyle, currently at St Andrews University, where he is professor of Human Geography, will be taking up, this September, the post of Chief Executive of the UK Economic and Social Research Council (ESRC) the main funder of UK social science research and longitudinal research resources. As Director of the ESRC-funded Longitudinal Studies Centre - Scotland, and the founder of the census-based Scottish Longitudinal Study, much of his career has been in longitudinal research, including writing a major report for ESRC on administrative data linkage. He is also an elected member of the recently established SLLS Executive Committee.

Karl Ulrich Mayer, previously professor of Sociology at Yale University, and emeritus professor at the Max Planck Institute for Human Development in Berlin is taking up, in the autumn of this year, the role of President of the Leibniz Institute for the Social Sciences - GESIS - in Berlin. This is the premier institute in Germany for supplying infrastructure services to the social sciences and conducting research. We are fortunate to have professor Mayer as our first keynote speaker at the SLLS conference in September.

\section{Events 2010}

ESHMS - (European Society of Health and Medical Sociology) $13^{\text {th }}$ Annual Congress, Ghent, Belgium, 26th28th August. Theme: 'Health and Well-Being in Radically Changing Societies'. http://www.eshms.org/Eshmsnews-2010-10-10\%20Ghent\%20Belgium.htm

ALSPAC - (Avon Longitudinal Survey of Parents and Children) Workshop. 'Longitudinal Data Analysis: Multilevel Modelling and Structural Equation Modelling Approaches'. 20-21 September. Bristol University, UK http://www.bristol.ac.uk/alspac-social-sciences/workshops/longitudinaldataanalysis.html

SLLS - (Society for Longitudinal and Life course Studies) Inaugural Conference and General Meeting, Clare College, Cambridge, UK, 22-24 September.

http://www.longstudies.longviewuk.com/pages/conference.shtml

CELSE 2010 - (Conference of Epidemiological Longitudinal Studies in Europe) Paphos, Cyprus, 13th-15th October. http://www.celse.eu/

LHRS Meeting - (Life History Research Society) $14^{\text {th }}-17^{\text {th }}$ October, Montreal, Canada http://crdh.concordia.ca/LifeHistory/ 


\section{NEWS, EVENTS AND RESOURCES}

\section{Events 2011}

SRCD - (Society for Research in Child Development) Biennial Meeting March 31 $^{\text {st }}-$ April $^{\text {nd }}$, Montreal, Canada. http://www.srcd.org

Volunteer Reviewer website http://www.srcd.org/submissions2011/volunteers.

SLLS - (Society for Longitudinal and Life Course Studies) Summer School, July $4^{\text {th }}-8^{\text {th }}$, University of Antwerp, Belgium, particularly for research post-graduates and post-doctoral fellows. Other sponsors include the European Association of Population Studies and CELLO (Centrum voor Longitudinaal en Levensloop Onderzoek - Research Centre for Longitudinal and Life Course Studies), University of Antwerp. Registration opens on 1 Sept 2010 at www.ua.ac.be/cello/summerschool.

\section{Resources}

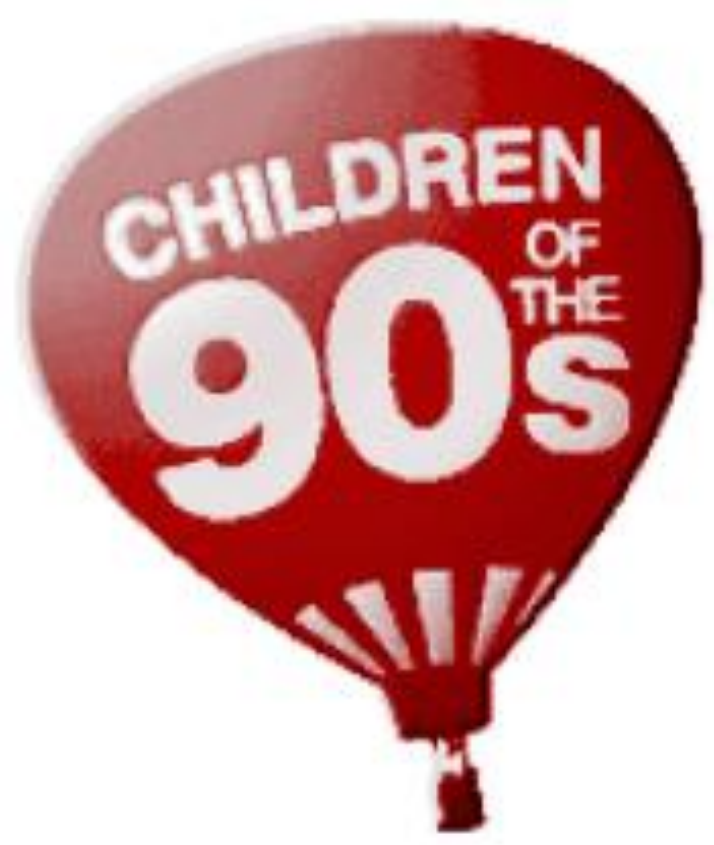

Avon Longitudinal Study of Parents And Children: the Social Science Edge

Eleanor Walsh, Social Scientist, University of Bristol

Now in its $20^{\text {th }}$ year of data collection, ALSPAC has become renowned in health and medical research circles. More recently however, ALSPAC has been recognised as a valuable resource for social science researchers. Geographers, criminologists, sociologists, economists, psychologists and statisticians alike are all using the ALSPAC data resource both within their own disciplines as well as in multidisciplinary research teams.

Not only does the ALSPAC data provide a retrospective look at health, environment and socio-economic factors in the Avon area since the 1990s, researchers are becoming interested in the potential impact of more recent changes in the UK. The impact of the economy on parents and children's employment and education, advances in technology and the "obesity epidemic", are particularly relevant today.

\section{Using ALSPAC data}

Researchers have gained insight into the data that is included in ALSPAC through the information held on the ALSPAC and ALSPAC social sciences websites. Access to the ALSPAC data has become increasingly popular. And the relative ease of the application and approval process has meant that

the number of collaborators has grown dramatically in the last few years. There really are infinite options with the ALSPAC data with many areas of potential research yet untapped. This is not unsurprising given that the ALSPAC data comprises (next page): 


\section{NEWS, EVENTS AND RESOURCES}

\begin{tabular}{|c|c|}
\hline \multicolumn{2}{|c|}{ Self Completion Postal Questionnaires (500000+ received) } \\
\hline \multirow{11}{*}{$\begin{array}{l}\text { Self-report measures of } \\
\text { physical activity } \\
\text { lifestyle } \\
\text { education } \\
\text { occupation } \\
\text { social environment } \\
\text { life events } \\
\text { health } \\
\text { depression \& anxiety } \\
\text { diet }\end{array}$} & Carers - about themselves \\
\hline & \\
\hline & Children - about themselves \\
\hline & \\
\hline & Carers - about their children \\
\hline & \\
\hline & Partners-about themselves \\
\hline & \\
\hline & Puberty - carers \& children \\
\hline & \\
\hline & Teachers \& Schools - about the children \\
\hline Hands on Assessments & ages $7-17$ \\
\hline $\begin{array}{l}\text { Biological Samples } \\
\text { (1 million collected) }\end{array}$ & DNA from over 10,000 young people \\
\hline Direct linkage to Administrative data & School and educational data \\
\hline Linked Datasets & $\begin{array}{l}\text { GIS and other geographic based data, growth } \\
\text { and development trajectories }\end{array}$ \\
\hline \multicolumn{2}{|l|}{ Environmental monitoring } \\
\hline Sub Studies & $\begin{array}{l}\text { GIS techniques to look at environmental } \\
\text { exposure }\end{array}$ \\
\hline
\end{tabular}

- For more information on what the ALSPAC database has to offer, visit www.bristol.ac.uk/alspac.

- To find out how you become an ALSPAC collaborator and use the data available, visit www.bristol.ac.uk/alspac-social-sciences

\section{ALSPAC Social Science User Group}

Many of these researchers are part of the ALSPAC Social Science User Group. This has been set up as part of an Economic and Social Research Council-funded grant. The development of the Social Science User Group aims to raise awareness of the ALSPAC database within the social science community and to encourage and support its usage by researchers. This is currently has over 300 members across the UK and internationally. The broad spectrum of social science research means that there are a wide range of researchers included in this group. Of course, with the inherent overlap between these disciplines, there is a breadth and depth of research interests involved. This user group is entirely collaborative, with those using ALSPAC data being invited to contribute to the project newsletter as a dissemination output for their ALSPAC-based research. For more information about signing up to the mailing list visit: www.bristol.ac.uk/alspac-social-sciences. 